\title{
Short-selling deregulation and corporate social responsibility of tourism industry in China
}

\author{
Wenzhen Mai ${ }^{1,2,{ }^{*}}$ and Dr Nik Intan Norhan Binti Abdul Hamid ${ }^{1}$ \\ ${ }^{1}$ Universiti Teknologi Malaysia, Johor Bahru, 81310, Malaysia \\ ${ }^{2}$ Guangdong Neusoft Institute, Guangdong, 528225, China
}

\begin{abstract}
This study aims to examine the impact of short selling constraints on corporate social responsibility (CSR) of listed tourism companies in China. Based on the external governance theory, it is hypothesized that short selling deregulation provides a monitoring function on CSR performance of tourism companies, which are highly exposed to social and environmental problems. A multiple linear regression is conducted with a panel data of Chinese 21 listed tourism firms between 2010 and 2018. The descriptive statistics show that average CSR score of Chinese tourism companies is 25.52/100, which represents low CSR performance of tourism industry. The regression results illustrate that short selling constraints relaxation can improve CSR performance of tourism companies. The findings of this study indicate that financial policymakers shall consider further relaxation of short selling constraints, which can be beneficial to industry, such as tourism, that are sensitive to CSR practices and performance.
\end{abstract}

\section{Introduction}

The tourism industry has demonstrated a significant position in China's national economy and social development in recent years. Given the lack of social responsibility of tourism businesses, the tourism industry has yielded a series of negative environmental and social problems, such as environmental degradation, environmental destruction, excessive depletion of energy, little protection of employment rights and interests as the size of the Chinese tourism market expanding. Therefore, tourism businesses are attributed to environmental and social problems by policymakers, non-profit organizations and the community. However, it is necessary to explore whether external corporate governance, such as the monitoring role of short-selling, can act as the motives for tourism companies to improve CSR practices.

Although short selling is available in developed markets for many years, China's regulatory authorities have relaxed its stock short selling restrictions since March 2010. Assessment of the negative effects of short selling is necessary in financial evaluation. The studies showed that short selling professionals are knowledgeable investors who can predict stock values, detect when a company is acting improperly, prevent financial chaos, and make a success of a business [1-3] .

CSR plays an essential part in developing global companies. Policy makers are aware of the necessity to improve CSR and promote and encourage sustainable development. Studies concerning CSR ownership structure, political, social, and cultural characteristics, CSR stock price reactions, and ethical factors have been performed. To promote an environment that is conducive to long-term growth, it is important to understand a company's internal motivation and external pressure to act $[4,5]$.

Prior research has proven that the short selling affect the corporate environment protection by increasing pollution related investments [6]. In terms of social issue, short selling will also contribute to the growing corporate philanthropy and donations [7]. However, there have been few scholars who realized the relationship between short selling and company's CSR performance. This paper claims that short selling ban lifting impacts the CSR performance of tourism industry in China.

In this paper, we use a multiple linear model with panel data of tourism companies listed in China from 2010 to 2018 to solve the problem of model misspecification and examine whether short selling deregulation will affect CSR performance. In particular, theoretical and managerial contributions are illustrated in this paper. Theoretically, this paper discusses the monitoring role of short selling on corporate sustainability. Based on the general idea that corporate executives will adopt reasonable CSR practices to defend the monitor and deterrence of short sellers, so tourism companies will be volunteering adopt and improve CSR performance when short selling threats are available. These findings help us to launch a stronger theoretical framework for the relationship between short selling and corporate social responsibility. 


\section{Literature Review}

It is important to understand the key factors influencing corporate sustainability and if short selling will boost CSR performance. Studies suggest that the social capital of the company is the major factor that affects the extent of the CSR performance.

Following the theory of external governance, short selling activities stimulate the detection of negative information from companies and increase the cost of seeking private benefits by managers, which can benefit from restricting their unethical behaviours and moral hazard [1]. To avoid the attacks of short selling behaviours, corporate managers tend to improve the CSR performance to demonstrate the long-term strategies of corporate sustainability.

When considering the monitoring role of short sellers on the employment responsibility, Brockman, Luo [2] presented US empirical results under Regulation SHO and stated that an increased threat of short selling could significantly improve employee relations, because shortsellers may aim to short sell stocks of firms with employee-related negative publicity. Besides, firms with a higher level of earnings manipulation, probability of labour disputes and employee whistle-blowing and reduced workplace concerns are the targets for shortsellers.

Short selling can provide incentives for the social responsibility of firms, Hou, Meng [7] empirically investigated the impact of short selling on the propensity to corporate philanthropy in Chinese firms. Drawing from a strategic business literature perspective, when a firm faces a sudden increase of short-sales, it has the incentive to divert public attention with corporate philanthropy. Additionally, short selling can also affect the pollution activities of companies. Wang and Zhang [6] examined how short selling affects firms' pollution protection policy with the empirical studies of Chinese listed companies. The deregulation of short-selling control would cause increased investments on pollution avoidance activities. The deterrence effect of short selling on environmental investments of firms is greater in SMEs with less institutional ownership and in more concentrated markets.

Tourism responsibility is best placed at the level of business self-regulation and that responsible conduct is preferred as a focus that often outweighs the issue of irresponsible conduct. Among many, CSR is positioned as one strategy to govern and address deviant tourism behaviour [8]. In addition, Uyar, Kilic [9] found that refined corporate governance is a monitor for tourism companies to conduct beneficial responsibility practices in all magnitudes of CSR, including environmental, social, and governance. Empirically, they adopt cross-country data in their study which expands the generalizability of the findings. CSR practices of tourism companies can be translated into better stages of sales revenue and corporate profitability, by evolving better customer and stakeholders' relations with the improvements of tourism marketing and reputation advantages.

Overall, this paper is inclined to hypothesise that short selling mechanism can improve CSR performance of listed tourism companies in China by improving benefits of stakeholders, employment relationship, social responsibility and internal control governance. Therefore, the hypotheses are examined as bellow:

H1: There is a positive relationship between the short selling deregulation and CSR performance of listed tourism companies in China.

\section{Methodology}

\subsection{Data and sample sources}

This paper uses data from 21 Chinese listed tourism companies from 2010 to 2019 as the scope of the sample. The financial data are from the China Stock Market and Accounting Research Database (CSMAR). The short-sale list data is acquired from Shenzhen Stock Exchange websites. CSR performance is obtained from Hexun.net database.

Suggested by the common practice in developed countries and China, ST* firms, firms that were previously shortable but later became non-shortable, and firms with missing related information are excluded in this research. This paper winsorise the data at the $1 \%$ and 99\% levels to mitigate the effects of outliers. After the above process, we preliminarily obtain a sample of 186 firm-years, including 3 firms in the shortable list and 18 firms out of the shortable list.

\subsection{Measurements of Variables and Model}

This paper needs to measure short selling constraint relaxation. Following Mai and Hamid [3], three sets of variables to measure deregulation of short selling, namely, LIST, PERIOD and LIST*PERIOD. LIST is the variable of short dummy, which is regarded as one if the stock is permitted to short during the sample period, and zero otherwise. PERIOD is a time dummy which equals 1 if the stock can be shortable by the end of current fiscal year, and zero otherwise. LIST *PERIOD is the interactive item for DID model which ensures that the firm value of a firm capture all of its activities over an entire fiscal year either before or after the exogenous shock.

For measuring CSR performance, this paper adopts CSR scores (CSR) from Hexun.net Database, which has a professional corporate social responsibility assessment framework with an adequate rating data towards CSR.

This paper adopts several control variables to capture the fundamentals of SMEs. Firm size (SIZE) is calculated as a natural logarithm of the market capitalisation, firm growth (GROWTH) is calculated as the market to book ratio, leverage (LEV) is measured as total liability divided by total assets, firm profitability (ROA) is calculated as net income divided by average total assets.

For Hypotheses 1, this paper explores whether deregulation of short selling has positive impact on CSR performance e by using the following model 1 :

$C S R=a 0+a 1$ LIST $*$ PERIOD + a2controls $+\varepsilon$ 


\section{Results and Discussions}

Table 1 presents the descriptive statistics for the variables in our study. For the 186 samples, the average CSR score is 25.5219 , unveiling the weak performance of social responsibility of tourism companies. The standard deviation is 12.6962 , indicating the difference among the responsibility practices of tourism industry. The average number of firm size, growth, leverage and ROA are $22.2379,0.0320,0.4123$ and 0.0518 respectively.

Table1. Descriptive Statistics

\begin{tabular}{cccccc}
\hline Variables & Samples & Mean & SD & Min & Max \\
\hline LIST*PERIOD & 186 & 0.0914 & 0.2890 & 0.0000 & 1.0000 \\
CSR & 186 & 25.5219 & 12.6962 & -5.4300 & 74.9000 \\
SIZE & 186 & 22.2379 & 0.9445 & 20.7012 & 25.8804 \\
GROWTH & 186 & 0.0320 & 0.1171 & -1.3356 & 0.3992 \\
LEV & 186 & 0.4123 & 0.4936 & 0.0503 & 6.2808 \\
ROA & 186 & 0.0518 & 0.0859 & -0.8604 & 0.2548 \\
\hline
\end{tabular}

Table 2 demonstrates correlations for the variables in our study. The overall correlation short-selling deregulation (LIST*PERIOD) and CSR performance of tourism industry (CSR) is not very high but significant in $1 \%$ confidence level, indicating the relationship between short-selling and CSR is positive. Despite firm leverage (LEV) is negative correlated to CSR, all other variables have positive correlation with CSR of tourism companies.

Table2. Correlation Analysis

\begin{tabular}{|c|c|c|c|c|c|c|}
\hline & $\begin{array}{l}\text { LIST* } \\
\text { PERIOD }\end{array}$ & CSR & SIZE & $\begin{array}{c}\text { GROWT } \\
\mathrm{H}\end{array}$ & LEV & ROA \\
\hline $\begin{array}{c}\text { LIST* } \\
\text { PERIOD }\end{array}$ & 1.0000 & & & & & \\
\hline CSR & $\begin{array}{c}0.2362^{* *} \\
*\end{array}$ & 1.0000 & & & & \\
\hline SIZE & $\begin{array}{c}0.6143^{* *} \\
*\end{array}$ & $0.2921^{* * *}$ & 1.0000 & & & \\
\hline $\begin{array}{c}\text { GROWT } \\
\mathrm{H}\end{array}$ & 0.0364 & 0.0716 & $0.1902 * * *$ & 1.0000 & & \\
\hline LEV & -0.0553 & $\begin{array}{c}-2562 * * * \\
-\end{array}$ & $\begin{array}{c}- \\
0.1950^{* * *}\end{array}$ & $-0.1839^{* *}$ & 1.0000 & \\
\hline ROA & $\begin{array}{c}0.2050^{* *} \\
*\end{array}$ & $0.4322 * * *$ & $0.3988^{* * *}$ & 0.0078 & $0.8363 * * *$ & $\begin{array}{c}1.000 \\
0\end{array}$ \\
\hline
\end{tabular}

Table 3 reveals the multiple linear regression results estimating the influence of short-selling deregulation (LIST*PERIOD) on CSR performance of tourism companies. The effect of control variables in the tourism industry was controlled throughout the analysis. The baseline regression model is designed to investigate the impact of short-selling on CSR performance. The regression tests the main effect of the key independent variable, short-selling deregulation (LIST*PERIOD). The coefficient is positive (5.1085) and significant ( $\mathrm{p}<5 \%$ ). This finding supported our hypothesis that short-selling deregulation can improve CSR performance of listed tourism companies in China. The results of this finding indicate that the threats of potential short selling after deregulation can act as external corporate governance which requires corporate executives in the tourism industry to perform better social responsibility activities.
Table3. Regression Result

\begin{tabular}{ccc}
\hline & \multicolumn{2}{c}{ CSR } \\
\hline Variables & Coefficient & Probability \\
\hline Intercept & 23.1314 & 0.3920 \\
LIST*PERIOD & $5.1085^{* *}$ & 0.0310 \\
SIZE & -0.3869 & 0.7590 \\
GROWTH & $15.2768^{*}$ & 0.0530 \\
LEV & $10.3381^{* * *}$ & 0.0030 \\
ROA & $11.5603 * * *$ & 0.0000 \\
adjrsquare & 0.2525 & \\
F-statstics & 12.16 & 0.0000 \\
$\mathrm{~N}$ & 186 & \\
\hline Note: ${ }^{*}, * * * *$ Denote significance at the $10 \%$, the $5 \%$, and the $1 \%$, respectively.
\end{tabular}

\section{Conclusions}

Corporate Social Responsibility (CSR) is a crucial way for tourism companies to realize long-term reproductive success and joint responsible growth of social and environmental improvement, particularly for the tourism industry which requires a high level of customer reputation. However, most studies on CSR are conducted in developed market economies, particularly in the United States and Europe. Therefore, in emerging markets, there is still a limited knowledge of social competence and sustainable development of tourism companies. In addition, few scholars drew attention on whether capital market mechanism can have positive impact on CSR performance. Therefore, this paper is designed to fill the gap to examine whether short selling deregulation can improve CSR in the context of Chinese tourism industry. The empirical results of this study confirm the hypothesis that CSR of tourism companies are improved after the specific companies are selected in the designated lists of short selling deregulation. The implication of this paper indicates that financial policymakers can consider further relax the constrains of short-selling activities in China, which will in turn benefit corporate social responsibility and other stakeholders in tourism industry.

For further analysis, it is practical to observe the relationship between short selling deregulation and CSR of tourism companies under different moderating factors such as different ownership identities, corporate governance level. In addition, the components of CSR shall also be examined thoroughly in order to determine which determinants of CSR are better affected by short selling mechanism. Lastly, this paper only focuses on tourism companies listed in China, but other eminent Chinese tourism companies are listed in US and Hongkong which are not selected in the scope of this paper. It is important to notice whether the relationship between short selling and CSR is also significant for Chinese tourism listed overseas markets.

\section{References}

1. Massa, M., B. Zhang, and H. Zhang, The invisible hand of short selling: Does short selling discipline earnings management? The Review of Financial Studies, 2015. 28(6): p. 1701-1736. 
2. Brockman, P., J. Luo, and L. Xu, The impact of shortselling pressure on corporate employee relations. Journal of Corporate Finance, 2020. 64.

3. Mai, W. and N.I.N.B.A. Hamid. Understanding the Effect of Short Selling Mechanism on Market Value of Pharmaceutical Industry in China Under Covid-19. in Basic \& Clinical Pharmacology\& Toxicology. 2020.

4. Hickman, L.E., Information asymmetry in CSR reporting: publicly-traded versus privately-held firms. Sustainability Accounting, Management and Policy Journal, 2020.

5. $\mathrm{Hu}, \mathrm{Y}$., et al., CSR and firm value: Evidence from China. Sustainability, 2018. 10(12): p. 4597.

6. Wang, S. and D. Zhang, Short-selling restrictions and firms' environment responsibility. Research in International Business and Finance, 2020. 54.

7. Hou, D., et al., Motives for corporate philanthropy propensity: Does short selling matter? International Review of Economics \& Finance, 2019. 63: p. 24-36.

8. Volgger, M. and S.S. Huang, Scoping irresponsible behaviour in hospitality and tourism: Widening the perspective of CSR. International Journal of Contemporary Hospitality Management, 2019.

9. Uyar, A., et al., The link among board characteristics, corporate social responsibility performance, and financial performance: Evidence from the hospitality and tourism industry. Tourism Management Perspectives, 2020. 35. 